\title{
Heart Muscle Performance after Experimental
}

\section{Viral Myocarditis}

\author{
C. O. Adesanya, A. H. Goldberg, W. P. C. Phear, K. A. Thorp, \\ N. A. Young, and W. H. Abelmann \\ From the Thorndike, Anesthesia and Channing Laboratories, Boston City \\ Hospital, and the Departments of Medicine and Anesthesia, Harvard Medical \\ School, Boston, Massachusetts 02215
}

A в S T R A C T As part of an inquiry into possible antecedents of idiopathic cardiomyopathy, acute experimental coxsackie virus myocarditis was studied for late structural and functional sequelae. Myocarditis was induced in 12- and 22-day-old hamsters by inoculation with coxsackie virus B3. Early viremia occurred, followed by virus replication in heart muscle.

Maximum peak developed tension ( $\mathrm{Tpd}$ ) of isometrically contracting isolated heart muscle was depressed 17 and $43 \%$ in the animals inoculated at 12 days, and studied 18 and 90 days later, respectively, as compared to their uninoculated controls. In both infected groups, less muscle stretch was required to reach the length at which Tpd was produced. Animals studied 180 days after inoculation did not differ from controls.

The muscles from animals inoculated at 22 days of age and studied 18 days later showed a $15 \%$ depression of $\mathrm{Tpd}$ compared to their controls. Glycerinated muscles from this infected group developed 50\% less tension than their controls. The muscles of hamsters inoculated with virus at 22 days and studied 90 and 180 days later showed no change in $\mathrm{Tpd}$.

The data suggest that contractility and compliance of heart muscle are decreased 18 days after inoculation, but recover by 90 days if the animals are inoculated at age 22 days. However, if the animals are inoculated at a younger age (12 days), depression of myocardial performance persists for at least an additional 90 days.

It is concluded that the inflammatory stage of experimental acute coxsackie virus B3 myocarditis in the

Presented, in part, at the 6th Annual Meeting of the International Study Group for Research in Cardiac Metabolism, 28 September 1973, Freiburg, West Germany.

Address reprint requests to Dr. Abelmann, Cardiovascular Unit, Beth Israel Hospital, Boston, Mass. 02215.

Received for publication 4 June 1975 and in revised form 31 October 1975.

The Journal of Clinical Investigation Volume 57 March 1976.569-575
Syrian golden hamster may be followed by residual alterations in contractile proteins and myocardial function.

\section{INTRODUCTION}

Viral myocarditis clinically is generally benign and recovery apparently complete (1). Yet, cases of persistent symptoms and cardiac manifestations with or without eventual recovery have been well documented $(2,3)$. Although chronic myocarditis and myocardial fibrosis have been postulated as sequelae of acute viral myocarditis, the evidence in man remains circumstantial (4). The occurrence of subacute myocarditis followed by myocardial fibrosis has, however, been seen in mice with experimental coxsackie virus B3 myocarditis (5). These clinical and experimental observations have raised the possibility that at least some cases of primary cardiomyopathy and congestive heart failure represent late sequelae of an earlier viral myocarditis, even in the absence of evidence of myocardial inflammation.

In the present study, this hypothesis was tested by inducing acute myocarditis in both suckling and weanling Syrian golden hamsters with coxsackie virus B3. Myocardial function was assessed 18, 90, and 180 days after inoculation by observing the isometric contractile response of isolated left ventricular trabeculae carneae during stretch.

In an attempt to further characterize the observed depression of contractility induced by viral infection in the isolated muscle, papillary muscles from weanling animals studied at 18 days were kept in glycerin for 3 mo, resulting in the essential destruction of all cell membranes including the sarcoplasmic reticulum $(6,7)$. This provided a more direct model for studying the contractile proteins. 


\section{METHODS}

Coxsackie virus B3 (Nancy strain), originally isolated from a human case of coxsackie virus infection, was serially propagated in cultures of Vero (African green monkey kidney) cells in serum-free medium $199(8,9)$. Syrian golden hamsters of the LSH strain (Lakeview hamster colony, Newfield, N. J.) were used. The animals were inoculated intraperitoneally with $10^{8}$ plaque-forming units $(\mathrm{PFU})^{1}$ of virus at either age 12 days (suckling) or 22 days (weanling). Age-matched control animals were sham inoculated with medium from uninfected cell cultures. Muscle mechanics were evaluated at 18,90 , and 180 days postinoculation.

The 12-day-old (suckling) group studied at 18 days postinoculation consisted of seven control $(\mathrm{C} / 12 / 18)$ and eight infected (I /12/18) hamsters. In the group examined at 90 days postinoculation, there were 6 control $(\mathrm{C} / 12 / 90)$ and 10 infected $(\mathrm{I} / 12 / 90)$ hamsters. At 180 days eight control $(\mathrm{C} / 12 / 180)$ and eight infected $(\mathrm{I} / 12 / 180)$ hamsters were studied. The animals in the $12 / 90$ group were inoculated separately from the other two 12-day groups. The weanling animals were inoculated at age 22 days, and were subdivided and studied as follows. One group studied at 18 days consisted of 7 control $(\mathrm{C} / 22 / 18)$ and 10 infected (I/22/18) animals. At 90 days, eight control (C/ $22 / 90)$ and eight infected $(\mathrm{I} / 22 / 90)$ animals were studied. At 180 days, nine control $(\mathrm{C} / 22 / 180)$ and eight infected (I/22/180) animals were studied.

Infectivity. Using age-matched animals that had received the same virus inoculum, the quantity of virus in blood and myocardium was assayed on days $1,2,3,5$, and 7 after inoculation. Serum-neutralizing antibodies were assayed by a plaque reduction method 90 days postinoculation. Possible cross-infection between cages was ruled out by assaying for neutralizing antibodies in the serum of control animals.

Pathology. Livers, lungs, and hearts were inspected for gross lesions and then weighed. Heart weight/body weight ratios were calculated. Sections of formalin-fixed, paraffinembedded tissues were stained with hematoxylin and eosin, Van Gieson, and Masson trichrome stains.

Muscle mechanics. The animals were decapitated, the left ventricular trabeculae carneae were rapidly dissected out, and the free ends of the muscle were connected to spring-loaded clamps. One of the clamps was attached to a Statham UC3 tension transducer (Statham Instruments, Inc., Oxnard, Calif.) and the other held rigidly. Peak-developed tension ( $T p d$ ) and resting tension $(\mathrm{Tr})$ were noted. Length changes were transduced with a Schaevitz LVDT 50 transducer. The isometric myograms were electronically differentiated to obtain the maximum rate of tension development $(\mathrm{d} T / \mathrm{d} t)$. The time-to-peak tension (TPT) was measured as the time from the onset of contraction to maximum $\mathrm{Tpd}$. $\mathrm{L}_{\max }$ was that length at which maximum $\mathrm{Tpd}$ was produced. $\mathrm{Tpd}, \mathrm{Tr}$, and $\mathrm{d} T / \mathrm{d} t$ were measured at $\mathrm{L}_{\max }$. All measurements were transcribed on a Honeywell U. V. recorder (Honeywell, Inc., Test Instruments Div., Denver, Colo.). The muscles were bathed in Ringer's solution of the following composition in milliequivalents per liter: sodium 146, potassium 5, calcium 2.25 , magnesium 2.5, chloride 130 , bicarbonate 25 , phosphate 1.4 , sulphate 2.5 , and $11 \mathrm{mM}$ glucose. The solution was per-

${ }^{1}$ Abbreviations used in this paper: $\mathrm{d} T / \mathrm{d} t$, maximum rate of tension development; $L_{1}$, initial length; PFU, plaqueforming units; Tpd, peak developed tension; TPT, time to peak tension; $\mathrm{Tr}$, resting tension. fused with $95 \% \mathrm{O}_{2}$ and $5 \% \mathrm{CO}_{2}$. The $\mathrm{pH}$ was $7.4 \pm 0.05$, and the temperature was maintained at $32.0^{\circ} \pm 0.1^{\circ} \mathrm{C}$. Each muscle was stimulated to contract isometrically once every $4 \mathrm{~s}$ with a biphasic stimulus of $6 \mathrm{~ms}$ duration set at $10 \%$ above threshold.

During an initial stabilization period of $15-20 \mathrm{~min}, \mathrm{Tr}$ was set for a minmum value $(<0.25 \mathrm{~g})$. After the muscles stabilized, we cyclically stretched and relaxed them, using a modification of a previously published method (10). We utilized a motor-driven variable-offset cam, the rotation of which caused vertical displacement of the tension transducer. Each cycle lasted $5 \mathrm{~min}$. The muscle length at which developed tension started to increase with no change in $\operatorname{Tr}$ was determined; this was designated initial length $\left(L_{1}\right)$. Adjustment of the offset cam over seven length/tension cycles allowed the determination of the amount of stretch required to place the muscle at $\mathrm{L}_{\max }$.

During the eighth and ninth cycles the calcium concentration was increased from 2.25 to $3.30 \mathrm{meq} / \mathrm{liter}$. The calcium concentration was then returned to $2.25 \mathrm{meq} / \mathrm{liter}$, and a final control cycle was performed.

Left ventricular papillary muscles of the 22/18 animals were suspended in $50 \%$ glycerin-phosphate buffer solution at $4^{\circ} \mathrm{C}$ for 2 days and then at $-20^{\circ} \mathrm{C}$ for $3 \mathrm{mo}$. The glycerin solution was changed daily for the first 3 days (11). At the end of $3 \mathrm{mo}$, each muscle was placed between spring-loaded clamps and suspended from a tension transducer as described above. The muscle was triple washed and then left in a solution containing $5 \mathrm{mM} \mathrm{MgCl}, 60 \mathrm{mM}$ $\mathrm{KCl}$ and $20 \mathrm{mM}$ histidine, and perfused with $95 \% \mathrm{O}_{2}$ and $5 \% \mathrm{CO}_{2}$. The $\mathrm{pH}$ was $7.4 \pm 0.1$, and the temperature was $32.0^{\circ} \pm 0.1^{\circ} \mathrm{C}$. After a stabilization period of $30 \mathrm{~min}$ at low resting tension ( $\operatorname{Tr}<0.25 \mathrm{~g}), 0.1 \mathrm{~cm}^{3}$ of $600 \mathrm{mM} \mathrm{ATP}$ was added to the muscle bath (giving an ATP concentration of $5 \mathrm{mM}$ ), and the amount of tension generated was measured and corrected for the cross-sectional area.

Significance of differences was evaluated by Student's $t$ test, with the exception of calcium potentiation data which were evaluated by analysis of variance.

\section{RESULTS}

In the first study 35 suckling animals (12-day-old) received viral inoculum, $(\mathrm{I} / 12 / 90) .16$ of these died during the first $2 \mathrm{wk}$. The remaining 19 animals and the associated control group, C/12/90, appeared healthy throughout the observation period. A second set of 95 suckling animals were inoculated later to provide animals for the $I / 12 / 18$ and $I / 12 / 180$ groups. These animals did not show the same mortality rates, but 42 of the inoculated animals fell below $1 \mathrm{SD}$ of their expected body weights and were rejected from the study. Most of these lighter and smaller animals had a misshapen body conformation and appeared to be runts.

All the weanling animals were inoculated simultaneously, at age 22 days, 100 animals receiving the virus inoculum. There were 10 deaths, all within the first 2 wk; all these animals were cannibalized before they could be examined. There were no deaths among the 50 age-matched animals which had been sham inoculated at the same time. All other animals appeared healthy throughout the observation period. None showed evidence of cardiac failure. 


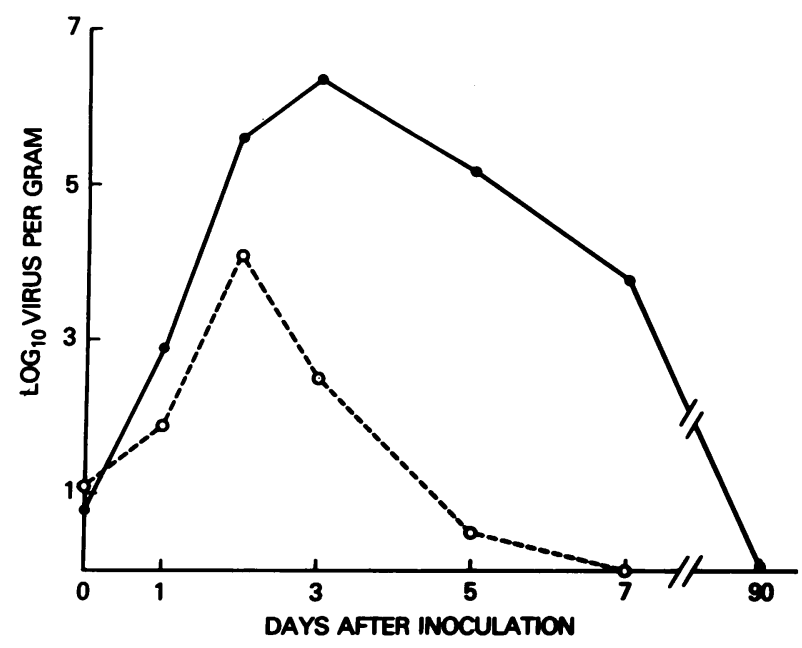

FIGURE 1 Coxsackie virus $\mathrm{B} 3$ in the blood $(\mathrm{O})$ and myocardium ( $\bullet$ ) of hamsters inoculated at age 12 days with $10^{\circ} \mathrm{PFU}$ intraperitoneally. Samples for virus assay were obtained $1 \mathrm{~h}$ after inoculation (day 0 ) and at the intervals indicated thereafter. Infectivity titers (mean value for three animals assayed at each time) are expressed as $\log _{10}$ $\mathrm{PFU} / \mathrm{g}$ of blood or myocardium.

Virology. Maximum viremia of $10^{4} \mathrm{PFU} / \mathrm{g}$ was present on day 2 after inoculation. On the 3rd day, virus replication was maximal in the heart (Fig. 1). Since peak virus concentrations exceeding $10^{\circ} \mathrm{PFU} / \mathrm{g}$ were found in heart tissue, the virus apparently replicated in the myocardium, and the presence of virus in the heart was not attributable merely to concomitant viremia. There was no residual virus in the myocardium 90 days after inoculation. Serum-neutralizing antibodies in the range of $1: 40-1: 160$ were present in all seven virus-inoculated hamsters studied at 90 days (22/90). No antibodies were detected in any of the 12 uninfected control animals studied.

Pathology. The heart weight/body weight ratios of the virus-inoculated animals were similar to those of the animals in their respective control groups (Table I). No gross abnormalities of the livers, lungs, or hearts were noted in either the control or infected animals, when they were sacrificed for the mechanical studies.

The only animal which died before study and was not cannibalized had been infected at 12 days in the first study, and on day 21 showed evidence of diffuse myocardial inflammation and necrosis.

On the 18th day after inoculation (12/18) focal infiltration was evident in only one-fifth of the animals, whereas at 90 days after inoculation (12/90) no infiltration was evident, but foci of necrosis were seen in one-third of the animals. At this stage, Van Gieson or Masson trichrome stains did not reveal any increase in connective tissue.

A total of 14 infected animals inoculated at age 22 days were sacrificed for histological examination, 3 on the 3rd day, 5 on the 5 th day, and 6 on the 7 th day after inoculation. The hearts of all the infected animals showed widespread inflammatory exudates and focal necrosis at this early stage of infection. This reaction was subsiding in the 13 animals examined at 18 days postinoculation when only $40 \%$ showed scanty focal myocytolysis. By the 90th and 180th day after inoculation all the hearts examined were normal.

Muscle mechanics. (Tables II and III): The average $L_{1}$ of the isolated trabeculae from all the virusinoculated animals were similar to those of their respective control groups. $L_{\max }$ was depressed in the in-

TABLE I

Heart Weight $(H W)$, Body Weight $(B W)$, and $H W / B W$ Ratios (Mean $\pm S E)$

\begin{tabular}{|c|c|c|c|c|c|c|c|c|c|}
\hline \multirow[b]{2}{*}{ Measurements } & \multicolumn{3}{|c|}{$12 / 18^{*}$} & \multicolumn{3}{|c|}{$12 / 90^{*}$} & \multicolumn{3}{|c|}{$12 / 180^{*}$} \\
\hline & Control & Infected & $P \ddagger$ & Control & Infected & $P \ddagger$ & Control & Infected & $P \ddagger$ \\
\hline Nos. & 7 & 8 & & 6 & 10 & & 8 & 8 & \\
\hline Heart weight, $g$ & $0.167 \pm 0.007$ & $0.156 \pm 0.007$ & NS & $0.368 \pm 0.007$ & $0.391 \pm 0.001$ & NS & $0.428 \pm 0.019$ & $0.462 \pm 0.013$ & NS \\
\hline Body weight, $g$ & $53.0 \pm 2.2$ & $47.1 \pm 2.7$ & NS & $110.0 \pm 3.46$ & $112.0 \pm 13.3$ & NS & $114.1 \pm 16.4$ & $133.4 \pm 19.1$ & NS \\
\hline \multirow[t]{3}{*}{$\mathrm{HW} / \mathrm{BW} \times 10^{-4}$} & $31.0 \pm 0.6$ & $33.4 \pm 0.6$ & NS & $33.4 \pm 1.2$ & $35.0 \pm 1.2$ & NS & $33.1 \pm 1.6$ & $32.9 \pm 0.7$ & NS \\
\hline & \multicolumn{3}{|c|}{$22 / 18^{*}$} & \multicolumn{3}{|c|}{$22 / 90 *$} & \multicolumn{3}{|c|}{$22 / 180^{*}$} \\
\hline & Control & Infected & $P \ddagger$ & Control & Infected & $P \nsucceq$ & Control & Infected & $P \ddagger$ \\
\hline Nos. & 7 & 10 & & 8 & 8 & & 9 & 8 & \\
\hline $\begin{array}{l}\text { Heart weight, } g \\
\text { Body weight, } g\end{array}$ & $\begin{array}{c}0.229 \pm 0.011 \\
72.0 \pm 4.3\end{array}$ & $\begin{aligned} 0.242 & \pm 0.006 \\
61.0 & \pm 3.5\end{aligned}$ & $\begin{array}{l}\text { NS } \\
\text { NS }\end{array}$ & $\begin{array}{l}0.327 \pm 0.001 \\
112.7 \pm 6.5\end{array}$ & $\begin{array}{l}0.322 \pm 0.008 \\
118.7 \pm 6.2\end{array}$ & $\begin{array}{l}\text { NS } \\
\text { NS }\end{array}$ & $\begin{array}{l}0.387 \pm 0.009 \\
130.8 \pm 6.1\end{array}$ & $\begin{array}{l}0.390 \pm 0.001 \\
128.5 \pm 3.5\end{array}$ & $\begin{array}{l}\text { NS } \\
\text { NS }\end{array}$ \\
\hline $\mathrm{HW} / \mathrm{BW} \times 10^{-4}$ & $33.7 \pm 1.7$ & $38.0 \pm 1.2$ & NS & $27.0 \pm 0.93$ & $27.4 \pm 0.99$ & NS & $30.3 \pm 0.69$ & $30.3 \pm 0.40$ & NS \\
\hline
\end{tabular}

* Age (days) of inoculation/age (days) of study.

¥ Statistical significance of difference between control and infected muscle groups.

HW/BW, heart weight/body weight ratios.

NS, not significant. 
TABLE II

Left Ventricular Muscle Mechanics: 12-Day Inoculation Calcium Concentration 2.25 meq/liter

\begin{tabular}{|c|c|c|c|c|c|c|c|c|c|}
\hline \multirow[b]{2}{*}{ Measurements } & \multicolumn{3}{|c|}{$12 / 18^{*}$} & \multicolumn{3}{|c|}{$12 / 90 *$} & \multicolumn{3}{|c|}{$12 / 180^{*}$} \\
\hline & Control & Infected & $P \ddagger$ & Control & Infected & $P \ddagger$ & Control & Infected & $P \ddagger$ \\
\hline Nos. & 7 & 8 & & 6 & 10 & & 8 & 8 & \\
\hline $\mathrm{CSA}, \mathrm{mm}^{2}$ & $0.77 \pm 0.08$ & $0.76 \pm 0.04$ & NS & $1.27 \pm 0.10$ & $1.19 \pm 0.05$ & NS & $1.76 \pm 0.12$ & $1.70 \pm 0.15$ & NS \\
\hline $\mathrm{L}_{\mathrm{i}}, \mathrm{mm}$ & $3.81 \pm 0.25$ & $3.73 \pm 0.20$ & NS & $5.44 \pm 0.21$ & $5.27 \pm 0.25$ & NS & $4.44 \pm 0.40$ & $4.84 \pm 0.18$ & NS \\
\hline $\mathrm{L}_{\max }, m m$ & $4.69 \pm 0.09$ & $4.45 \pm 0.06$ & $<0.05$ & $7.28 \pm 0.10$ & $6.27 \pm 0.10$ & $<0.001$ & $5.94 \pm 0.38$ & $6.39 \pm 0.17$ & NS \\
\hline Stretch, \% & $+24.3 \pm 1.7$ & $+18.9 \pm 0.9$ & $<0.05$ & $+28.9 \pm 1.42$ & $+19.7 \pm 1.63$ & $<0.001$ & $26.20 \pm 2.22$ & $24.36 \pm 1.01$ & NS \\
\hline$T p d, \mathrm{~g} / \mathrm{cm}^{2}$ & $56.48 \pm 2.42$ & $47.07 \pm 3.93$ & $<0.05$ & $112.31 \pm 5.39$ & $64.22 \pm 9.90$ & $<0.001$ & $145.0 \pm 13.29$ & $138.77 \pm 11.20$ & NS \\
\hline $\mathrm{d} T / \mathrm{d} t, \mathrm{~g} / \mathrm{s} / \mathrm{cm}^{2}$ & $432.4 \pm 31.0$ & $337.1 \pm 25.7$ & $<0.05$ & $836.0 \pm 90.1$ & $467.6 \pm 70.8$ & $<0.01$ & $886.3 \pm 117.7$ & $768.4 \pm 62.7$ & NS \\
\hline $\mathrm{Tr}, \mathrm{g} / \mathrm{cm}^{2}$ & $53.48 \pm 2.99$ & $51.76 \pm 2.65$ & NS & $83.41 \pm 10.11$ & $97.14 \pm 5.13$ & NS & $73.26 \pm 9.87$ & $83.74 \pm 11.89$ & NS \\
\hline TPT, $s$ & $0.083 \pm 0.003$ & $0.072 \pm 0.002$ & $<0.001$ & $0.94 \pm 0.002$ & $0.090 \pm 0.002$ & NS & $0.093 \pm 0.003$ & $0.091 \pm 0.003$ & NS \\
\hline
\end{tabular}

All measurements were taken at $\mathrm{L}_{\max }(\mathrm{Mean} \pm \mathrm{SE})$.

* Age (days) of inoculation/days postinoculation.

‡ Statistical significance of differences between control and infected groups.

CSA, cross-sectional area.

$L_{\max }$, length at which maximum $T_{p d}$ is produced.

fected muscles, $5 \%(P<0.05)$ for $\mathrm{I} / 12 / 18$ and $14 \%$ for $\mathrm{I} / 12 / 90(P<0.001)$. The extent of stretch from $\mathrm{L}_{1}$ to $\mathrm{L}_{\max }$ was also less in these two groups. Furthermore, Tpd was depressed $17 \%$ in $\mathrm{I} / 12 / 18(P<0.05)$ and $43 \%$ in $\mathrm{I} / 12 / 90(P<0.001)$ (Fig. 2$) ; \mathrm{d} T / \mathrm{d} t$ was depressed $22 \%(P<0.05)$ and $44 \%(P<0.01)$, respectively. $\mathrm{Tr}$ and TPT in these groups were unchanged compared to those of the control groups. The control and infected muscles of the $12 / 180$ group showed no significant differences in any of these parameters.

The infected animals inoculated at age 22 days ( $\mathrm{Ta}$ ble III) and studied after 18 days (I/22/18) demonstrated a reduction of $7 \%(P<0.001)$ in $\mathrm{L}_{\max }$ and $18 \%$ $(P<0.001)$ in TPT when compared to the control muscles. The extent of stretch from $L_{1}$ to $L_{\max }$ was significantly less compared to the control. Tpd at $\mathrm{L}_{\max }$ was decreased 25\% $(P<0.05)$ (Fig. 3). Although $\mathrm{d} T / \mathrm{d} t$ was reduced by $40 \%$ in this group, this did not achieve statistical significance. The $\operatorname{Tr}$ showed no difference between the control and infected groups.
The control and infected muscles of $22 / 90$ and $22 / 180$ groups had similar values for $\mathrm{L}_{\max }, \mathrm{Tpd}, \mathrm{d} T / \mathrm{d} t, \mathrm{Tr}$, and TPT.

When the calcium ion concentration of the muscle bath was increased from the standard 2.25 to $3.30 \mathrm{meq} /$ liter (Table IV), Tpd was increased $46.9 \%(\mathrm{C} / 12 / 18)$, $20.5 \%(\mathrm{C} / 12 / 90)$, and $57.0 \%$ in the $\mathrm{C} / 22 / 18$ muscles. In the infected animals, these increases were $38.4 \%$ $(\mathrm{I} / 12 / 18), 15.8 \%(\mathrm{I} / 12 / 90)$, and $32.3 \%(\mathrm{I} / 22 / 18)$. Thus Tpd was potentiated to a significantly greater extent in the control muscles. Only in the younger animals was $\mathrm{d} T / \mathrm{d} t$ significantly increased. There were no significant differences between control and infected muscle groups in the calcium-induced potentiation of $\mathrm{d} T / \mathrm{d} t$. TPT and Tr were not dependent on the external calcium concentration.

Tpd, $d T / d t$, TPT, and Tr of both the control and infected muscles increased proportionally but not linearly with age (Tables II and III).

TABLE III

Left Ventricular Muscle Mechanics: 22-Day Inoculation Calcium Concentration 2.25 meq/liter

\begin{tabular}{|c|c|c|c|c|c|c|c|c|c|}
\hline \multirow[b]{2}{*}{ Measurements } & \multicolumn{3}{|c|}{$22 / 18^{*}$} & \multicolumn{3}{|c|}{$22 / 90^{*}$} & \multicolumn{3}{|c|}{$22 / 180^{*}$} \\
\hline & Control & Infected & $P \ddagger$ & Control & Infected & $P \ddagger$ & Control & Infected & $P \ddagger$ \\
\hline Nos. & 7 & 10 & & 8 & 8 & & 9 & 8 & \\
\hline $\mathrm{CSA}, m m^{2}$ & $1.60 \pm 0.05$ & $0.73 \pm 0.11$ & $<0.05$ & $1.22 \pm 0.16$ & $1.13 \pm 0.12$ & NS & $1.46 \pm 0.19$ & $1.70 \pm 0.14$ & NS \\
\hline $\mathbf{L}_{\mathrm{i}}, m m$ & $4.06 \pm 0.32$ & $4.19 \pm 0.32$ & NS & $4.90 \pm 0.26$ & $4.79 \pm 0.40$ & NS & $5.79 \pm 0.12$ & $5.28 \pm 0.15$ & NS \\
\hline $\mathrm{L}_{\max , m m}$ & $4.96 \pm 0.11$ & $4.62 \pm 0.08$ & $<0.001$ & $5.75 \pm 0.27$ & $5.54 \pm 0.45$ & NS & $6.83 \pm 0.18$ & $6.21 \pm 0.19$ & NS \\
\hline Stretch, \% & +22.5 & +16.3 & $<0.001$ & +30.6 & +21.4 & NS & +20.7 & +18.1 & NS \\
\hline $\mathrm{Tpd}, \mathrm{g} / \mathrm{cm}^{2}$ & $63.72 \pm 5.56$ & $47.93 \pm 10.75$ & $<0.05$ & $131.24 \pm 16.1$ & $152.2 \pm 30.2$ & NS & $171.9 \pm 23.4$ & $131.8 \pm 11.9$ & NS \\
\hline $\mathrm{d} T / \mathrm{d} t, \mathrm{~g} / \mathrm{s} / \mathrm{cm}^{2}$ & $543.64 \pm 54.53$ & $326.55 \pm 75.74$ & NS & $833.2 \pm 99.4$ & $900.0 \pm 179.3$ & NS & $1046.5 \pm 141.4$ & $787.5 \pm 81.6$ & NS \\
\hline $\mathrm{Tr}, \mathrm{g} / \mathrm{cm}^{2}$ & $57.12 \pm 6.69$ & $53.81 \pm 3.2$ & NS & $71.78 \pm 14.50$ & $69.0 \pm 10.3$ & NS & $84.4 \pm 9.4$ & $68.7 \pm 9.0$ & NS \\
\hline TPT, s & $0.084 \pm 0.002$ & $0.069 \pm 0.002$ & $<0.001$ & $0.082 \pm 0.001$ & $0.080 \pm 0.003$ & NS & $0.086 \pm 0.001$ & $0.085 \pm 0.020$ & NS \\
\hline
\end{tabular}

All measurements were taken at $\mathrm{L}_{\max }$ (Mean $\pm \mathrm{SE}$ ).

* Age (days) of inoculation/days postinoculation.

¥ Statistical significance of differences between control and infected groups. 

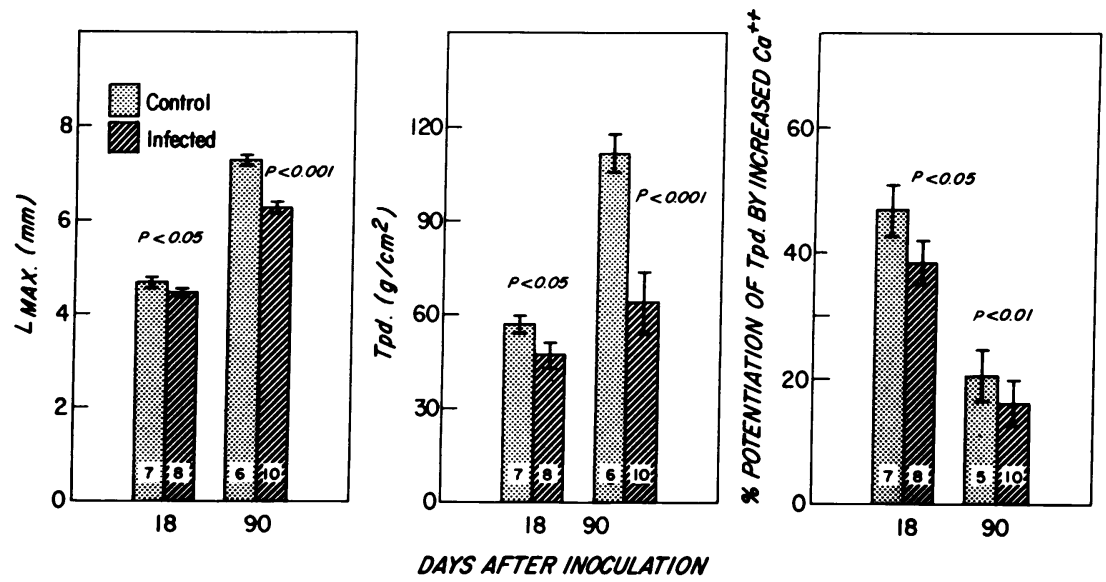

FIgURE 2 Muscle mechanics performed on the 18th and 90th day postinoculation of 12-day-old hamsters. (Mean $\pm \mathrm{SE}$ ). The infected muscle groups had shorter muscle length and less Tpd at their optimum length ( $\mathrm{L}_{\max }$ ) than control muscles. Additional external calcium ion concentration potentiated $\mathrm{Tpd}$ in all groups, but the potentiation was greater in the control groups. The size of each group is shown within the bar graphs.

After glycerin extraction, previously infected papillary muscles from the $22 / 18$ group generated $50 \%$ less $(P<0.02)$ tension $\left(127.50 \pm 60.02 \mathrm{~g} / \mathrm{cm}^{2}\right)$ than their control muscles $\left(342.82 \pm 35.83 \mathrm{~g} / \mathrm{cm}^{2}\right)$.

\section{DISCUSSION}

Heart failure of unknown etiology has gained increasing attention. There is a small but persistent number of patients who present with end-stage heart failure, in whom valvular heart disease, hypertensive heart disease, coronary artery disease, and congenital heart disease have been eliminated as the etiology. It is possible that some cases of such idiopathic cardiomyopathy might represent late sequelae of previous viral myocarditis (4).
Viral infections of man and experimental animals frequently involve the heart. In particular, infections with group B coxsackie viruses are now recognized as the most common cause of acute myocarditis $(3,12$ 16). Moreover, Wilson et al. (5) have shown that mice infected with group B coxsackie viruses may develop permanent pathological changes in the myocardium. Similar suggestive evidence exists for human disease. Sainani et al. (2) reported 22 patients with proven coxsackie myocarditis, most of whom recovered within a few weeks or months. Five patients, however, had persistent signs of heart failure, as well as electrocardiographic abnormalities. Virus-like particles have been
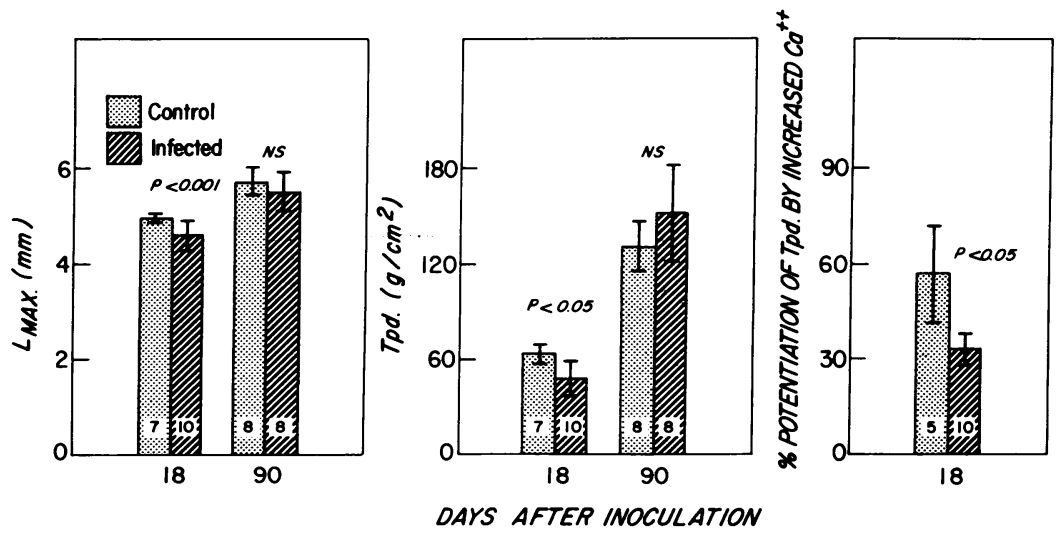

FIGURE 3 Muscle mechanics performed on the 18th and 90th day postinoculation of 22-dayold hamsters. (Mean \pm SE). 18 days postinoculation, the infected muscle group had shorter optimum lengths $\left(\mathrm{L}_{\max }\right)$, less $\mathrm{Tpd}$, and showed less potentiation of $\mathrm{Tpd}$ upon addition of calcium compared to control group. On the 90th day postinoculation infected muscles no longer differed from control muscles. The size of each group is shown within bar graphs. 
described in the heart of a patient with cardiomyopathy by Hibbs et al. (17).

In the present study, intraperitoneal inoculation of Syrian golden hamsters with coxsackie virus B3 resulted in acute myocarditis, as evidenced by initial acute focal necrosis and inflammatory exudates associated with viral replication in the heart tissue. Measurements of serum-neutralizing antibodies, moreover, indicated that all the virus-inoculated animals became infected. By the 90th day, however, virus was absent from the heart tissue, and the inflammatory exudates had disappeared. The high spontaneous mortality and morbidity rates in the animals inoculated at age 12 days suggest that a more virulent infection occurred in the animals inoculated at a younger age. Runting in rodents in response to viral, including coxsackie virus, infections, has been reported previously $(18,19)$.

Depressed contractility of the isolated trabeculae was observed when myocarditis was induced in the younger suckling animals (12-day-old). This depression persisted for at least 90 days (12/90), but recovered before 180 days. It is known that suckling rodents are more susceptible to coxsackie virus infection (20), and it is therefore possible that more extensive viral replication in young animals results in a more severe and longer lasting effect on the myocardium. This hamster model of coxsackie virus myocarditis, therefore, appears to simulate human viral myocarditis, which is more severe in infants than in adults.

Although the hearts of $12 / 90$ animals showed no microscopic evidence of residual scarring or fibrosis, contractility was still depressed. Dissociation between functional and morphologic lesions as detected by light microscopy was thus evident. However, electron microscopic examination of the myocardium might detect damage at the ultrastructural level.

Myocarditis induced in older weanling animals (22day-old) resulted in an initial (18 days postinoculation) depression of contractility of the isolated trabecula. However, by 90 and 180 days after inoculation, there was no significant difference in the contractile performance of the hearts of infected animals compared to their respective controls. This suggests that recovery had taken place. The lack of evidence for continuing inflammation or significant residual scarring is consistent with this view.

In muscle groups $12 / 18,12 / 90$, and $22 / 18$ the $L_{1}$ of the infected and control muscles were the same, as were the $\operatorname{Tr}$ at $L_{\max }$. The increase in length (stretch) required to place the infected muscles at $L_{\max }$ was significantly less than that required for the control muscles. This suggests that the compliance of the infected muscles was decreased.

TABLE IV

Left Ventricular Muscle Mechanics: Calcium Concentration 3.30 meq/liter

\begin{tabular}{|c|c|c|c|c|c|c|c|c|c|}
\hline \multirow[b]{2}{*}{ Measurements } & \multicolumn{3}{|c|}{$12 / 18^{*}$} & \multicolumn{3}{|c|}{$12 / 90^{*}$} & \multicolumn{3}{|c|}{$22 / 18 *$} \\
\hline & Control & Infected & $P \ddagger$ & Control & Infected & $P \ddagger$ & Control & Infected & $P \ddagger$ \\
\hline Nos. & 7 & 8 & & 5 & 10 & & 7 & 10 & \\
\hline Tpd, $\mathrm{g} / \mathrm{cm}^{2}$ & 83.26 & 65.38 & & 153.97 & 74.24 & & 89.97 & 65.47 & \\
\hline & \pm 4.80 & \pm 6.11 & $P<0.05$ & \pm 17.59 & \pm 11.66 & $P<0.01$ & \pm 12.60 & \pm 15.55 & $P<0.05$ \\
\hline Change from $\left(\mathrm{Ca}^{2+}\right)$ & +46.9 & +38.3 & & +20.5 & +15.8 & & +57.0 & +32.3 & \\
\hline $\begin{array}{l}2.25 \text { meq/liter, } \% \\
P \S\end{array}$ & $\begin{array}{l} \pm 3.8 \\
P<0.001\end{array}$ & $\begin{array}{l} \pm 3.8 \\
P<0.05\end{array}$ & $P<0.05$ & $\begin{array}{l} \pm 4.3 \\
P<0.05\end{array}$ & $\begin{array}{l} \pm 4.2 \\
P<0.05\end{array}$ & $P<0.01$ & $\begin{array}{l} \pm 16.4 \\
P<0.05\end{array}$ & $\begin{array}{l} \pm 5.1 \\
P<0.05\end{array}$ & $P<0.05$ \\
\hline $\mathrm{d} T / \mathrm{d} t, \mathrm{~g} / \mathrm{cm}^{2} / \mathrm{s}$ & 568.62 & 489.44 & & 967.81 & 547.60 & & 777.30 & 419.72 & \\
\hline Change from $\left(\mathrm{Ca}^{2+}\right)$ & $\begin{array}{l} \pm 47.47 \\
+45.8\end{array}$ & $\begin{array}{l} \pm 41.85 \\
+45.0\end{array}$ & $P<0.05$ & $\begin{array}{l} \pm 93.35 \\
+14.5\end{array}$ & $\begin{array}{l} \pm 80.00 \\
+18.8\end{array}$ & $P<0.02$ & $\begin{array}{l} \pm 58.70 \\
+32.5\end{array}$ & $\begin{array}{l} \pm 93.52 \\
+36.6\end{array}$ & NS \\
\hline $\begin{array}{l}2.25 \text { meq/liter, \% } \\
P \S\end{array}$ & $P \stackrel{ \pm 4.5}{<0.05}$ & $\begin{array}{l} \pm 4.3 \\
P<0.01\end{array}$ & NS & $\begin{array}{r} \pm 3.5 \\
\mathrm{NS}\end{array}$ & $\begin{array}{c} \pm 5.0 \\
\text { NS }\end{array}$ & NS & $P \stackrel{ \pm 4.9}{<0.05}$ & $\begin{array}{l} \pm 8.0 \\
P<0.05\end{array}$ & NS \\
\hline $\mathrm{TR}, \mathrm{g} / \mathrm{cm}^{2}$ & 52.36 & 51.15 & & 86.07 & 100.51 & & 54.97 & 52.68 & \\
\hline & \pm 3.06 & \pm 3.13 & NS & \pm 11.04 & \pm 6.66 & NS & \pm 5.80 & \pm 15.56 & NS \\
\hline Change from $\left(\mathrm{Ca}^{2+}\right)$ & -2.0 & -1.4 & & -0.3 & +3.8 & & +3.2 & +1.8 & \\
\hline $\begin{array}{l}2.25 \text { meq/liter, \% } \\
P \S\end{array}$ & $\begin{array}{c} \pm 2.4 \\
\text { NS }\end{array}$ & $\begin{array}{c} \pm 2.2 \\
\text { NS }\end{array}$ & NS & $\begin{array}{r} \pm 3.8 \\
\text { NS }\end{array}$ & $\begin{array}{r} \pm 3.2 \\
\text { NS }\end{array}$ & NS & $\begin{array}{c} \pm 4.1 \\
\text { NS }\end{array}$ & $\begin{array}{c} \pm 2.9 \\
\text { NS }\end{array}$ & NS \\
\hline TPT, s & $\begin{array}{r}0.084 \\
\pm 0.003\end{array}$ & $\begin{array}{r}0.072 \\
\pm 0.003\end{array}$ & $P<0.001$ & $\begin{array}{r}0.093 \\
\pm 0.002\end{array}$ & $\begin{array}{r}0.090 \\
\pm 0.002\end{array}$ & NS & $\begin{array}{r}0.085 \\
\pm 0.004\end{array}$ & $\begin{array}{r}0.071 \\
\pm 0.003\end{array}$ & $P<0.001$ \\
\hline Change from $\left(\mathrm{Ca}^{2+}\right)$ & +2.5 & +1.7 & & +1.6 & +0.3 & & +6.3 & +4.4 & $1-0.001$ \\
\hline $\begin{array}{l}2.25 \text { meq/liter, \% } \\
P \S\end{array}$ & $\begin{array}{c} \pm 3.1 \\
\mathrm{NS}\end{array}$ & $\begin{array}{l} \pm 2.3 \\
\text { NS }\end{array}$ & NS & $\begin{array}{c} \pm 3.4 \\
\text { NS }\end{array}$ & $\begin{array}{c} \pm 2.9 \\
\text { NS }\end{array}$ & NS & $\begin{array}{l} \pm 5.4 \\
\text { NS }\end{array}$ & $\begin{array}{l} \pm 5.2 \\
\text { NS }\end{array}$ & NS \\
\hline
\end{tabular}

All measurements taken $\mathrm{L}_{\max }$ (Mean $\pm \mathrm{SE}$ ).

* Age of inoculation/days postinoculation.

‡ Statistical significance of differences between control and infected groups.

Statistical significance of difference between calcium of concentrations 2.25 and 3.30 meq/liter (by analysis of variance). 
The potentiation of Tpd upon exposure to additional calcium suggests that the contractile reserve of the infected muscle was not significantly impaired. The study of glycerinated muscle fibers, as a model for actomyosin contractility $(6,7,21-23)$, suggests the possibility of viral-induced abnormalities of actin and or myosin.

In conclusion, when young hamsters (12-day-old) were infected with coxsackie virus B3, there was an early myocardial dysfunction which persisted for at least 90 days. However, infection of older animals (22day-old) resulted in a similar initial dysfunction which was followed by a subsequent return to normal function. The myocardial abnormality might involve alterations of the contractile proteins.

The results of the present study suggest that, in the hamster, structural and functional myocardial alterations secondary to acute coxsackie virus B3 may persist well beyond the stage of virus replication and inflammatory response. If this is also the case in man, residual effect of acute viral myocarditis may well play a role in later cardiomyopathy and heart failure.

\section{ACKNOWLEDGMENTS}

We wish to thank Miss Sarah Braun for clerical assistance.

This work was supported, in part, by grants HL 10539 and HL 5244 from the National Heart and Lung Institute, by grant $1168-\mathrm{F}$ from the Massachusetts Heart Association, and by the Paul Dudley White Fund, Harvard Medical School.

\section{REFERENCES}

1. Abelmann, W. H. 1973. Clinical aspects of viral cardiomyopathy. In Myocardial Disease. N. O. Fowler, editor. Grune \& Stratton, Inc., New York. 253-279.

2. Sainani, G. S., G. Krompotic, and S. J. Slodki. 1968. Adult heart disease due to the coxsackie virus $B$ infection. Medicine (Baltimore). 47: 133-147.

3. Smith, W. G. 1970. Coxsackie B myopericarditis in adults. Am. Heart J. 80: 34-46.

4. Abelmann, W. H. 1973. Viral myocarditis and its sequelae. Annu. Rev. Med. 24: 145-152.

5. Wilson, F. M., Q. R. Miranda, J. L. Chason, and A. M. Lerner. 1969. Residual pathologic changes following murine coxsackie $\mathrm{A}$ and $\mathrm{B}$ myocarditis. $\mathrm{Am}$. J. Pathol. 55: 253-265.

6. Bendal, J. R. 1969. Muscles, Molecules, and Movement. American Elsevier Publishing Co., Inc., New York. $58 \mathrm{pp}$.
7. Rome, E. 1973. Structural studies by x-ray defraction of striated muscle permeated with certain ions and proteins. Cold Spring Harbor Symp. Quant. Biol. 37: 331.

8. Young, N. A. 1973. Polioviruses, coxsackie viruses and echoviruses: comparison of the genomes by RNA hybridization. J. Virol. 11: 832-839.

9. Young, N. A., B. H. Hoyer, and M. A. Martin. 1968. Polynucleotide sequence homologies among polioviruses. Proc. Natl. Acad. Sci. U. S. A. 61: 549-555.

10. Bassett, A. L., S. M. Ross, and B. F. Hoffman. 1967. An apparatus for varying the length of isolated heart muscle. J. Appl. Physiol. 22: 813-817.

11. Szent-Györgyi, A. 1949. Free-energy relation and contraction of actomyosin. Biol. Bull. (Woods Hole). 96: 140-161.

12. Bates, H. R., Jr. 1970. Coxsackie virus B3 calcific pancarditis and hydrops fetalis. Am. J. Obstet. Gynecol. 106: 629-630.

13. Burch, G. E., and H. K. Colcolough. 1969. Progressive Coxsackie viral pancarditis and nephritis. Ann. Intern. Med. 71: 963-970.

14. Abelmann, W. H. 1971. Virus and the heart. Circulation. 44: $950-956$

15. Hudson, R. E. 1965. Cardiovascular Pathology. The Williams and Wilkins Co., Baltimore. 1: 779 pp.

16. Burch, G. E., and T. D. Giles. 1972. The role of viruses in the production of heart disease. Am. J. Cardiol. 29: 231-240.

17. Hibbs, R. G., V. J. Ferrans, W. C. Black, J. J. Walsh, and G. E. Burch. 1965. Virus-like particles in the heart of a patient with cardiomyopathy. An electron microscopic and histochemical study. Am. Heart J. 69: 327337.

18. Hammon, W. M., and G. E. Sather. 1969. Arboviruses. In Diagnostic Procedures for Viral and Rickettsial Infections. E. H. Lennette and N. J. Schmidt, editors. American Public Health Association, Inc., New York. $4^{4} \mathrm{~h}$ edition. 227-280.

19. Melnick, J. L., and H. A. Wenner. 1969. Enteroviruses. In Diagnostic Procedures for Viral and Rickettsial Infections. E. H. Lennette and N. J. Schmidt, editors. American Public Health Association, Inc., New York. 4th edition. 529-602.

20. Burnstein, T. 1960. Relative susceptibility of young mice and hamsters to coxsackie B-3 virus. Proc. Soc. Exp. Biol. Med. 105 : 306-308.

21. Briggs, F. N. 1958. Factors influencing contraction in glycerinated myocardial fibers. J. Pharmacol. Exp. Ther. $124: 43-46$.

22. Taeschler, M., and R. J. Bing. 1953. Some properties of contractile proteins of the heart as studied on the extracted heart muscle preparation. Circ. Res. 1: 129-134.

23. Wise, R. M., J. F. Rondinone, and F. N. Briggs. 1971. Effect of calcium on force-velocity characteristics of glycerinated skeletal muscle. Am. J. Physiol. 221 : 973979. 